\title{
In The Light of What We Know: Issues of Politics and Exile
}

\author{
Shampa Iftakhar
}

\begin{abstract}
In the Light of What We Know is a big, ambitious, debut novel from Bangladeshi author Zia Haider Rahman. Rahman explores the story of two immigrants from very different class backgrounds. In the novel, we find an unnamed narrator. $\mathrm{He}$ is a banker from a privileged background .His grandfather was Pakistani ambassador to the US, and his parents are Oxford academics. Zafar, on the other hand, was born in Sylhet, a "corner of a corner"[1] of north-eastern Bangladesh. Their stories unfold from their conversation, and from Zafar's notebooks. The story gracefully and deftly explores the different issues such as entire nature of life, existence, love, belonging, math, free-will, politics, identity, quantum physics and so on. It also depicts a strong sense of homelessness of an immigrant who never gets back home. The story covers the most significant events of different countries i.e. Liberation War of Bangladesh, issues of 9/11, condition of Afghanistan, etc. In a strict sense, Rahman's In the Light of What We Know is not a political one. Even he addresses and explores these political issues to put forward very critical issues of politics from 1971 to 2011. The narrator's friend never gets a home in abroad. England never welcomes him. He is exiled from root. He feels anger within himself for this exile. This paper aims to focus on particularly of these two issues politics and exile that we find in the novel, In The Light of What We know.
\end{abstract}

Index Terms-Anger, immigrants, sense of homelessness, 9/11, The Liberation War of Bangladesh.

\section{INTRODUCTION}

In the book Reflections o Exile and Other Essays, Edward Said has defined exile. He mentions: "Exile is strangely compelling to think about but terrible to experience. It is the unhealable rift forced between a human being and a native place, between the self and its true home: its essential sadness can never be surmounted. And while it is true that literature and history contain heroic, romantic, glorious, even triumphant episodes in an exile's life, these are no more than efforts meant to overcome the crippling sorrow of estrangement [2].

Zia Haider Rahman's debut novel In the Light of What We Know starts with this famous quotation. In the novel, he introduces us an angry young man, named Zafar. Zafar is exiled from his root and from his family. The story of this novel gets exposed by an unnamed narrator who is a close friend of Zafar. In the online book review, Louise Adler mentions that this unnamed narrator exposes Zafar's "alienation, rage and despair" [3] by the help of "research, access to notebooks and a recorded three-month

Manuscript received March 17, 2016; revised September 14, 2016.

Shampa Iftakhar is with the Daffodil International University, Bangladesh (e-mail: shampa.eng@daffodilvarsity.edu.bd). conversation"[3]. Both of them tell us stories of "exile and home"[1]. Their stories also include "deracination and belonging, colonialism and post-colonialism, mathematics and art, faith and doubt, the East and the West, America and Afghanistan, the rich and the poor, the disenfranchised and the powerful, the immigrant and the native Briton, Washington and Kabul" [3]. The novel exposes different political events and their aftermath also. Different political and historical events are presented. We get some references to Liberation war of Bangladesh. The novel assesses the 9/11, aftermath financial crisis and Western outlook to Muslims. Zafar and the narrator talk about "exile and immigration, warfare, Wall Street and financial trading, contemporary geopolitics, Bangladesh, Pakistan, Afghanistan, English and American society, Islamic terrorism, Western paternalism, Oxford and Yale "[4]. This paper will focus on political issues of the Liberation War of Bangladesh, 9/11 and Zafar's exile.

\section{NARRATOR AND ZAFAR: EXILED IMMIGRANTS}

The novel opens in 2008. After many years narrator who is an investment banker receives a visitor i.e. Zafar. In the narrator words," The man appeared to be in a state of some agitation, speaking, as he was, not incoherently but with a strident earnestness and evidently without regard for introductions" [1]. The novel begins when the narrator is passing a real hard time. The narrator is separated from his wife who was a banker too. He has given his penchant for mortgage- backed securities, from his job. He welcomes Zafar as they were friends from their university days. "Like Zafar, I was a student of mathematics at Oxford" [1]. He gives him a room and then with the aid of Dictaphone and his friend's meticulous notebooks, he attempts to transcribe Zafar's tragic, tortuous tale. His tale takes us from London to Kabul, from New York to Islamabad. We meet his girlfriend Emily Hampton-Wyvern. We know about short love story and betrayal. Zafar's sudden appearance after many years plunges him back into their separate and shared memories of the last few decades. Their flashbacks will cover a lot of physical and metaphorical ground: as the narrator sums up, this is "the story of the breaking of nations, war in the twenty-first century, marriage into the English aristocracy, and the mathematics of love"[1].

Rahman's narrator remains nameless throughout the duration of the tale. He is of Pakistani origin. He grew up in Princeton. He is a banker from a privileged background. His grandfather was Pakistani ambassador to the US. His parents are Oxford academics. In Princeton, his father was a physics professor.

Narrator's friend, Zafar is not privileged like him. He was 
born in Bangladesh after Liberation War of Bangladesh. He is the son of working-class Bangladeshi immigrants to Britain. In London, his father worked as a bus conductor, and also as a waiter. Sometimes at Britons, people think that his root is in India. Sometimes, they assume that he grew up with servants. Like the narrator, he went to Oxford and studied mathematics and worked in Finance. But he feels "for wherever in the world we had lived ", in Bangladesh or in London, his family, as he puts it, "were the staff" [1].

Zafar passed his boyhood in a village in Bangladesh. Then he stayed in a "rat-infested squat" in London [1]. Zafar has been marked with an acute sign of his poverty. Zafar confesses," Childhood poverty looms over one's whole life" [1]. As Amitav, in his review of In the Light of What We Know indicates," as an immigrant in England, moving among privilege, and also as a Muslim, Zafar is a mixture of hurt and yearning and aggression. [5] Though he is more intellectual and brighter than many Westerns, he has been marked with a threat. He admitted that when he was recalling an incident at the United Nations compound in Kabul. He claimed what he felt, "the ever-present threat, whenever I was talking, that I'd drive a bulldozer over social norms" [1].

As the story proceeds, we come to know about Zafar's displacement, homelessness, and his discovery that he is not his parents' biological son". We learn that his father was a Pakistani soldier who raped his mother, "the young sister of the man who raised him as his own son." [1]. He hardly felt any family bond with them. "..The people whom I called my mother and my father were not my biological parent" [1]. He had always sensed an "emotional gulf" [1]. At the same time, he was unable to be rooted in different culture. He recalled his childhood memory. In his childhood, when his family took him at a seaside resort in England to spend vacation, he got introduced with an English family. When he was asked for his name, Zafar replied, "George" [1]. He chose a different name to make him comfortable with a white family. His exile was deeply rooted that he could not escape from.

Interestingly, Wood claims that Zia Haider Rahman's own life has focused in the certain points of the novel [4]. The writer was born in Bangladesh but brought up in England. He has his new home in England but when looks back to old home, Bangladesh he feels " bound " to "judge" both homes " critically" as he claims, "...the lucky recipient bound to judge his old home critically, seeing it, with fresh eyes, from the unjust luxury of his new home; bound also to judge his new home critically, seeing it from the unjust impoverishment of his old one; and now effectively estranged from either place" [4]. Wood also states that Rahman novelizes "this dynamic of homelessness" by two main characters of this novel. Zafar's ultimate quest to reassess some of his personal issues put forward the condition of being exiled [4].

In the novel, there are two betrayals. Emily betrayed Zafar and the narrator, Zafar's friend also betrayed him. In the Light of What We Know is a tragic story of Zafar's yearning to belong, and his final exile from belonging. In the mid-nineteen-nineties, in New York, Zafar was working as a derivatives trader. There he had met Emily Hampton-Wyvern. She is beautiful, flirtatious, withholding, properly liberal, and socially impeccable. Zafar first set eyes on Emily when they were both at Oxford. She and Zafar become a couple. But their relation is not worth mentioning. She rarely introduces him to any of her friends. After two months of their relationship, Zafar proposes her to marry him. She does not reply. "She let out a little laugh, a perfectly formed ladylike laugh. Just enough. And I said nothing more" [1]. Emily never utters the word "Sorry" [1].

Wood mentions in his book review mentions, "Emily is the Englishness that Zafar cannot possess" [4]. No one is very much welcoming to Zafar. No one visits him when he has been admitted in psychiatric hospital. Doctor comments, "You're here because of Emily" [1]. Zafar confesses his desire to be rooted. He is happy to know that Emily becomes pregnant. But Emily gets herself aborted. For him, a child means "to fix something in me" [1]. The narrator declears, "the child had mattered to him for reasons that gathered from every corner of his identity" [1]. Even England is unwelcoming. He claims, "If an immigration officer at Heathrow had ever said 'Welcome home', "I would have given my life for England, for my country, there and then. I could kill for an England like that" [1]. So, he is obsessed with a bitter idea about England and Emily. Wood points out that the bitterness he feels about Oxford, about Emily, about England, is turned against the Western development agencies in Afghanistan, whom he considers an "army in all but name" [1]. Zafar, from the core of his heart, hates the confident beneficence of Emily and her colleagues. He also accuses them of "playing the game as it's always been played: the game of Empire and Ego" [1]. He claims that "everything seen by the West is seen through the West," [1]. The narrator also feels alienated in America. He states, "I stood there as a witness to the overwhelmed idea of America," [1]. He is not rooted in Pakistan or in USA. The narrator's parents never "discuss Pakistani politics" or "Pakistan" but their eat " Pakistani" food at home"[1]. They act like refugee.

\section{THE LIBERATION WAR OF BANGLADESH AND EXILE}

The novel torches light on Liberation War of Bangladesh. Mookherjee reports that during the 1971 Bangladesh war for independence, members of the Pakistani military and supporting Bihari and Razaker militias raped between two and four hundred thousand Bangladeshi women in a systematic campaign of genocidal rape [6]. Scholz Sally in the article titled "Genocide" mentions in the immediate aftermath of the war, one pressing problem was the very high number of unwanted pregnancies of rape victims. Estimates of the number of pregnancies resulting in birth range from 25,000 [7].

Rahman never forgets the dirty politics of America in Liberation war of Bangladesh. From 25 March 1971, the Pakistani Army launched a devastating crackdown on the rebellious Bengalis in the east. Nixon and Kissinger supported the Pakistan. Bass J Gary in his book The Blood Telegram: Nixon, Kissinger and a Forgotten Genocide explores their roles and showed their utmost cruelty to exercise power on other countries. America ignored Archer K. Blood's telegram where he mentioned "a systematic genocide" of Pakistani armies but Kissinger called him "a maniac" and sneered at people who "bleed" for "the dying 
Bengalis" [8]. So very intentionally, Rahman presents us a protagonist who is a product of war. What he searches is a home. The narrator also feels that he "was driven" in order to" find a home in the world of books" [1]. But his alienation and aloofness make him behave desperately. As Said views that "isolation and displacement" can produce "the kind of narcissistic masochism that resists all efforts at amelioration, acculturation and community" [2]. He also mentions, "At this extreme the exile can make a fetish of exile, a practice that distances him or her from all connections and commitments "[2]. No doubt, Zafar is in the extreme state of exile. So he justifies his rape. He has raped Emily twice. Interestingly, Emily in this novel is presented as an alien. Hannah in her book review claims that she is introduced as almost a non-entity and we are never given evidence that Emily has feelings or thoughts of any depth [9]. She often treats Zafar as a pet rather than a real person. She prefers to spend more time with friends. On the other hand, Zafar feels no emotional bond with her. As Hannah mentions, "... he looks at Emily's body as if it were a piece of clockwork and not as a person that thinks and feels" [9]. Zafar also confesses that he attracted to her for her surname and her position of privilege. No doubt, he is charmed by sexual act with Emily. In his own words, "The sex was extraordinary. For me, I mean" [1]. He furthers mentions:

"Sure, there was spontaneous sex in unlikely places. There was enough of the drama, but what I mean is that it was powerful. It was almost always fucking, animal-like, but fucking in the head of me. It was not so much that she was good at sex rather that the idea of Emily never failed to arouse me. I felt moved greater and greater efforts and attention. I learned more and more about the workings of her body, the pathways of stimulus and response. Sex was the realm in which I could take control of her being, the only place where I could approach understanding, so that sometimes -quite often, in fact- her body became an extension of mine [1].

His uttered sentences remind the readers the mass rape of Pakistani armies. His homelessness and absence of emotional bond from the beginning of his life turns him into a masochist. His exile produces barbarity. He is product of barbarity so he has inherited barbarity in his blood. His genetics plays a large role to mould his psychology. Kendler in his studies supports this view. He mentions that genes affect aspects of the social environment, such as exposure to stressful life events and levels of social support, which in turn feedback on risk of illness [10].

\section{AFGHAN ISSUE AND EXILE}

In chapter 2 of this book, the narrator states, "Before 9/11, I was invisible unsexed. How is it that after 9/11 suddenly I was noticed -not just noticed, but attractive, given the second look, sized up even winked at?" [1].

Preston in his book review claims, this novel is the "an exploration of the post-9/11 world" [11]. The American-Arab Anti-Discrimination Committee (2003) reports that the event of 9/11 changed the outlook of the world about Muslims [12]. In 2003, the report of Council of American Islamic Relations states the same view. In the research work, Saroglou \&
Galand (2004) also observe that during the process of adjusting to the aftermath of September 11, Muslim Americans faced an upsurge in negative stereotypes expressed by the larger society and Muslim immigrants, more than any other immigrant group, were met with negative attitudes [13]. American pretends to be very welcoming to give citizenship to the people who are from different countries. Here no can ignore the issues of geopolitics. Wilson mentions in his book review of In the Light of What We Know, "here are lessons in geopolitics. In Kabul, when the UN and the NCOs arrived, locals who spoke English well were lured from their jobs as teachers and business managers to the better-paid life of drivers and other Western servants. The individuals were better off but the country became less productive. Meanwhile, the Taliban sold their homes to Western diplomats: real-estate values went through the roof and the Taliban made money" [14].

To be certain, the events of September 11 had a very profound effect upon the United States (particularly for Muslims and Middle Eastern Americans) as well as the entire world order. It is largely accepted as a fact that after the events of September 11, the Muslims American community suffered a backflash of hate and crime of discrimination [12]. In the Chapter 14, Rahman gives a clear indication of this fact. Westerns think Muslims are" lawless"[1]. At the same time, a muslim can hardly keep faith on another muslim. So the Pakistani colonel very easily mentions to Zafar that Mohammad Ahmed Hasan looks like a "spy". ".. he looks it, don't you think? " [1].

For the time being, Zafar feels for America. "My emotions ran high when I called the collapse of the towers. America had my heart and she had been wounded" [1]. But he understands later, in America he is an outsider, " " I felt no tie to America at that moment, as I might have done, nothing in the way of being at home" [1]. He confesses, after 9/11 he feels "a difference" when he is" speaking to a Westerner" [1].

Rahman implicitly discloses the main reason for America's attack on Afghanistan and boldly criticizes the role of Saudi Arabia. "Yes of course oil is at the root. Oil and business" [1]. These lines echo the voice of Steve Coll. In his book Ghost Wars, he mentions that the United States had made the decision to invade Afghanistan two months before the 9/11 attacks [15]. Rashid (2002) in his book entilted Taliban: Militant Islam, Oil and Fundamentalism in Central Asia boldly explores that at least part of the background to this decision was the United States' long-time support for UNOCAL's proposed pipeline, which would transport oil and natural gas from the Caspian Sea region to the Indian Ocean through Afghanistan and Pakistan. Rahman mentions Saudia Arabia's role after 9/11 [16]. "On September 12 ${ }^{\text {th }}, 2001$, the Saudis pumped out an extra nine million barrels of oil, most of it for the American markets" [1]. He further mentions that after 9/11, the Saudi royal family " keeps oil prices low" as " they've earned protection or a blind eyes from America, as the royal family's needs dictate "[1]. In the big ideas novel, In the

Light of What know Rahman successfully revisits the political issues of 9/11 and its impact to immigrated Muslims in America. 


\section{CONCLUSION}

John Milton in Paradise Lost writes:

"But the hot hell that always in burns,

Though in mid heaven, soon ended his delight,

And tortures him now more, the more he sees,

Of pleasure not for him ordained: then soon

Fierce hate he collects."[17].

These wonderful lines describe the ultimate pain and anger of an exiled archangel. Satan, in disguise, feels extremely wounded and lonely as he is no more belonged to this heaven. Like Satan, Zafar is angry and his words proves so," I have been full of anger my whole life, and if I've seemed to you or anyone as having been as calm as the kind of thinking that mathematics demands, then it is the only because the anger had yet to find expression"[1]. Now in the early hours of September morning, he comes to his friend to the pursuit of knowledge. He needs "knowledge" not in order to "better himself" but as Zafar claims to his friend " to lay ground for his feet to stand upon; in order that is , to go home, somewhere, and take root"[1]. Emily never waits for him; his friend, the narrator, never "called him" or "sent a note"[1]. during his stay at hospital. Zafar feels the futility of his pursuit like Kurt Gödel's Incompleteness Theoram: "Within any given system, there are claims which are true but which cannot be proven to be true." He is intellectual but his intellectuality makes him aware of his exile. As narrator claims, "Zafar was an exile, a refugee, if not from war, then of war, but also an exile from blood" [1]. All he needs is a home.

\section{REFERENCES}

[1] Z. H. Rahman, In the Light of What we Know, Newyork: Farrar, Starus and Giroux, 2014.

[2] W. E. Said, Reflections of Exile and Others Essays, Harverb University Press, 2002.

[3] L. Adler. (September 2014). Book Review: In the light of What We Know. Rev. of In the Light of What We Know, by Z. H. Rahman. The Sydney Morning Herald. [Online]. Avaliable: http://www.smh.com.au/entertainment/books/book-review-in-the-ligh t- of-what-we-know-by-zia-haider-rahman-20140901-10axos.html

[4] J. Wood. (May 2014). The World As We Know It: Zia Haider Rahman's dazzling début. Rev. of In the Light of What We Know, by Z. H. Rahman. The New Yorker. [Online]. Available: http://www.newyorker.com/magazine/2014/05/19/the-world-as-we-k now-it.

[5] K. Amitava. (April 2014). The Banker, the Visitor, His Wife and Her Lover. Rev. of In the Light of What We Know, by Z. H. Rahman. Sun Day Book Review. [Online]. Available: http://www.nytimes.com/2014/04/13/books/review/in-the-light-of-wh at-we-know-by-zia-haider-rahman.html?_r=1

[6] N. Mookherjee, "Mass rape and the inscription of gendered and racial domination during the Bangladesh War of 1971," in Rape in Wartime,
R. Branche, F. Virgili, and P. Macmillan, Eds. New York, pp. 67-78, 2012.

[7] S. J. Scholz and D. K. Chatterjee. Genocide encyclopedia of global justice. [Online]. Available: http://www.worldcat.org/title/encyclopedia-of-global-justice/oclc/772 633396

[8] J. G. Bass. The Blood Telegram: Nixon, Kissinger and a Forgotten Genocide. Hurst Publishers, New York, 2013.

[9] H. G. Hannah. (Sep. 2014). What female characters? Rev. of In the Light of What We Know, by Z. H. Rahman. The Los Angeles Book Review. $\quad$ [Online]. Available:
and https://lareviewofbooks.org/review/female-characters

[10] K. S. Kendler, "Twin studies of psychiatric illness: an update," Arch Gen Psychiatry, vol. 58, pp. 1005-1014, 2001.

[11] A. Preston. (October 2014). Zia Haider Rahman's 'epic and intensely moving' debut. Rev. of In the Light of What We Know, by Z. H. Rahman. The Observer. [Online]. Available: http://www.theguardiancom/books/2014/jun/01/in-light-what-we-kno w-review-zia-haider-rahman-epic-intensely-moving-debut

[12] American-Arab Anti-Discrimination Committee, "Report on hate crimes and discrimination against Arab Americans: The post-September 11 backlash, September 11, 2001-October 11, 2002," American-Arab Anti-Discrimination Committee Research Institute, Washington, DC., 2003.

[13] V. Saroglou and P. Galand, "Identities, values, and religion: A study among Muslim, other immigrant, and native Belgian young adults after the 9/11 attacks," Identity: An International Journal of Theory and Research, vol. 4, no. 2, pp. 97-132, 2004.

[14] S. Wilson. (2015). In the light of what we know by Zia Haider Rahman. [Online]. Available: http://www.metromag.co.nz/culture/books/zia-haider-rahman-in-the-1 ight-of-what-we-know-review

[15] S. Coll, Ghost Wars, Penguin Group, UK, 2004.

[16] A. Rashid, Taliban: Militant Islam, Oil and Fundamentalism in Central Asia, Yale University Press, USA. 2000.

[17] J. Milton. (2001). Paradise Lost. University of Virginia, USA. [Online]. Available: http://people.virginia.edu/ jdk3t/ParadiseLostIn10Bks1667.pdf

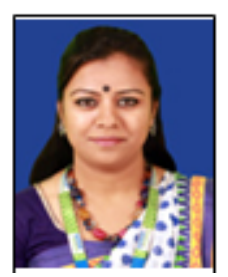

Shampa Iftakhar is an assistant professor, with the Department of English, she was born in Bangladesh on January 1, 1979. She has obtained her B.A. (Hons) and MA degrees in English literature from Jahangirnagar University, Bangladesh. She has been teaching for twelve years. She started her career as a teacher of Oxford International School, Dhaka. Then she joined in Stamford University Bangladesh. She joined in Daffodil International University. From 2004 to 2016, she has been teaching both language and literature courses.

She has got some of her papers published in different journals. Her recent publications include "Paths of Glory: Injustice and Crime against Humanity" published in International Journal of Languages, Literature and Linguistics, vol. 1, no. 3, September 2015. Her paper entitled "Google Classroom: What Works and How?" has been accepted for publication in the Journal of Education and Social Sciences, vol. 3, Feb. 2016.

She has presented papers in different national and international conferences. Recently she presented paper in 21st NELTA conference on 7 March, 2016. The title of her paper was "English Studies: A Case Study of Our Female Students' Perspective," her research areas include technology in education, Daspora literature, history, film and literature and ELT. 